\title{
Hybrid Delivery of Computer Literacy Requirements for Undergraduate Business Schools: A New Model for a New Millennium
}

\author{
Kathryn A. Marold \\ Metropolitan State College of Denver \\ USA \\ maroldk@mscd.edw
}

\author{
János T. Füstös \\ Metropolitan State College of Denver \\ USA \\ fustos@mscdedu
}

\begin{abstract}
The paper presents a revised model for handling the computer literacy and information systems requirements for undergraduates. The model was proposed for School of Business students at the Metropolitan State College of Denver. Through a combination of entrance screenings, self-paced Web Based Training courses on the campus network, and traditional classroom Introduction to Computers courses, a more efficient model for computer literacy was established. Then a hybrid model to deliver the introductory information systems class was proposed-to save scarce faculty and campus resources, yet preserve the traditional classroom instruction that some students need. The proposed hybrid model takes into consideration the higher level of computer literacy of many modern students, and takes advantage of the newest methods of interactive Web based training that make self-paced courses a practical means of learning.
\end{abstract}

Keywords: information systems, computer literacy, hybrid delivery, computer course, undergraduate, education

\section{Introduction}

Today, the advantage of all college graduates (not just business school graduates) possessing basic computer skills is not even contested. Only a score of years past, including computer literacy, as a graduation requirement was still being hotly debated by educators (Molnar, 1997.) From the mid-eighties on, it was generally accepted that all business school graduates should be able to use microcomputers for basic problem solving, at least at the operational end-user level. It was expected that students should be able to use the current application programs to satisfactorily perform word-processing, spreadsheet and database manipulations, and communicate via email. They should know file management and basic operating systems commands. All colleges offered introduction to computers and introductory information systems classes. Many schools had required computer literacy courses. Campus computer labs prolifer-

Material published as part of this proceedings, either on-line or in print, is copyrighted by the author with permission granted to the publisher of Informing Science for this printing. Permission to make digital or paper copy of part or all of these works for personal or classroom use is granted without fee provided that the copies are not made or distributed for profit or commercial advantage AND that copies 1) bear this notice in full and 2) give the full citation on the first page. It is permissible to abstract these works so long as credit is given. To copy in all other cases or to republish or to post on a server or to redistribute to lists requires specific permission from the author. ated, and some schools even required all entering freshmen to own a personal computer (Molnar, 1997.) All business schools had an entry-level information systems class in their core curriculum. The question was not whether students should be computer literate; it was how to achieve this goal. Basic models of computer applications inclusion in the business curriculum evolved. Generally, the computer information systems department of the business school was charged with offering an introductory service information systems course to cover this need. There were many varieties of the same basic model of students successfully passing one (sometimes two) semester or quarterlong courses to prove that they were, indeed, computer literate enough to function in the work force.

The business curriculum at Metropolitan State College was similar to that of any other business school. We offered a general lower-level service course, Introduction to Computers, to impart basic computer literacy skills. We then required microcomputer literacy for entrance into the introductory information systems course that all business students were required to take. In this course the students progressed through common horizontal business productivity programs, such as Word, WordPerfect, Lotus, Excel, dBase, and Access. They were introduced to file management and basic operating systems concepts. They learned to communicate via email, and to upload and download files from the campus minicomputer. There was a basic 


\section{Hybrid Delivery of Computer Literacy Requirements}

computer literacy screening test before students took the 2010 Principles of Information Systems course. Whether the student acquired his/her basic computer skills from high school, from our 1010 course, from work experience, or from using his/her own home computer was irrelevant. We simply requested a score of $60 \%$ or better on a general screening pretest. The screening test was compiled by several instructors with deep teaching experience at the introductory computer level; it was modified every two years to incorporate hardware and software changes in the microcomputer environment.

The progression of scores on the computer literacy screening evaluation over the last decade of this century reflect what was obvious: the saturation of the PC among our culture, and the better inclusion of computer curriculum in the primary and secondary schools resulted in a much more computer literate 2010 student body. Figure 1 shows the progression of averages on the Computer Literacy Screening Evaluation for years 1993 to 2000 at Metro.

The longitudinal study showed that students were coming into the introductory information systems course more computer literate each year. For a decade we adjusted the content of the computer applications portion of the course, covering more, and at a greater depth than in years past. By the late nineties, the presence of self-paced, and often Internet deployed, Introduction to Computers courses increased. The saturation of computers in American households has moved from 15 per cent to $22 \%$, to $35 \%$, and finally to $50 \%$ in 1999 (Time, 1999.). Studies that measured end user computing success found time and again that as individuals perception of the usefulness of the microcomputer increased, they were more receptive to learning how to incorporate it into their daily tasks (Shayo, 1999.) Also, access to electronically mediated instruction via software programs and the World Wide Web became affordable (Payson, 1998.) Studies on the effectiveness of computer based training courses showed that they were, indeed, as successful as traditional classroom based instruction, and students could use them with many different learning styles (Bowman, 1995; Hall, 1997; Marold, 1998. (a)). It was time to propose a new model for handling the computer literacy and introductory information system theory requirements for business students. The descriptions of the 1010 WBT (Web Based Training) for Basic Computer Skills and the 2010 Hybrid Delivery Model that follow recount what was proposed and why. There are plans to implement the newest model on a pilot basis in the fall semester of 2001 .

\section{Background of the Proposed Hybrid Model}

There has been much research on the success of self-paced individual learning, whether via computer aided instruction or a traditional distance education correspondence course. The individualized nature of the text-based computer assisted training modules of the late sixties progressed to the more sophisticated and highly interactive multimedia WBTs (Web Based Training) courses (Marold, 1998. (b)) Today, the "little Web schoolhouse" has become a reality (Dager, 1998.) However, even before the World Wide Web

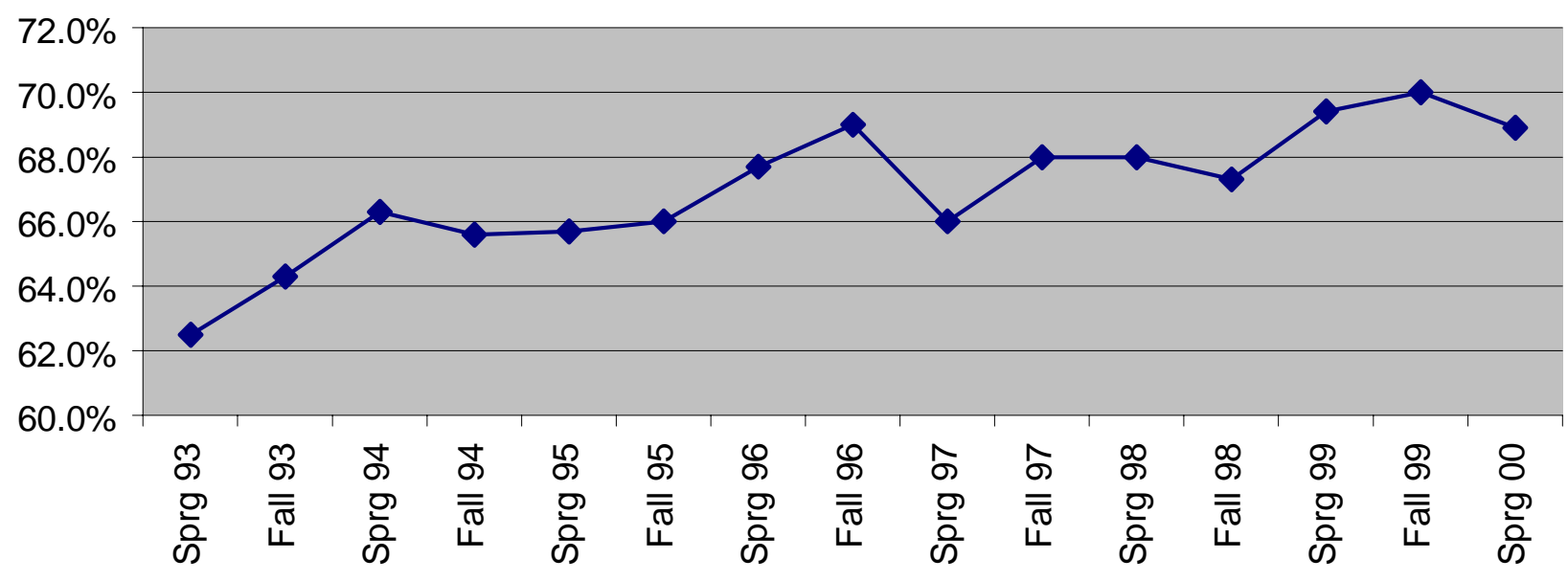

$n=>20$ sections of 30 students each

Figure 1: Longitudinal Study of CIS 2010 Computer Literacy Screening Evaluations 


\section{Kathryn A. Marold \& János T. Füstös}

became a practical delivery method for learning, we knew that computer based training worked (Ganger, 1990.) Educators everywhere began studying how technology could augment and enhance the educational process (Withrow, 1997.) Correspondence and video self-paced courses gave way to instructional services online. The promise of electronic tutelage became a reality (Marold, 1994.) Yet, the method of delivery of the traditional classroom instruction remained basically the same. Granted, the presentation of lecture material went from "chalk and talk" to much more sophisticated and appealing PowerPoint slide presentations, and student research papers cited as many Web URLs as hardcopy library researched articles. But delivery of the traditional academic course remained essentially the same as it had for hundreds of years. The "hands-on" structured lab session component of our beginning information systems course was the last real change in delivery of the course. That change was implemented in the late eighties when computer labs finally had enough workstations to accommodate a full class of students, and the campus labs were networked.

\section{Traditional model gives way to electronic tutelage model}

Although our CIS department offered Internet sections of both the Introduction to Computers course and the newly renamed Computer Applications for Business course, we were not using the Internet for its potential to deliver traditional classroom courses. If we could combine the best elements of our classroom sections, capitalizing on the deep experience of our full-time professors, yet use the excellent software training skills of our adjunct professors, while at the same time tap the "electronic tutelage" potential of the Web, we might have a hybrid model that benefited everyone.

Adapting a course for Internet delivery--even hybrid delivery--must be approached with a great deal of planning and care. Simply translating text to HTML-coded Web pages is a misuse of the medium; the course would be doomed to failure. Mcgrath found that technology increased student motivation, but the student-teacher relationship within such courses changes significantly (1998.) The old model of the master scholar imparting knowledge to the passive student is no longer valid. The teacher is now more of a "facilitator" than ever--a guide to the student's personal discovery. The Web site is now the course "library" (Burgstahler, 1997.) Done properly, the course is more individually in- teractive than the classroom of thirty students could ever be. Learning can occur any time, any place, when the student is most ready; this is the model learning theorists most advocate (Shank, 1995.) Planning and designing a course that contains a Web component requires knowing instructional design principles, graphic design, media psychology, project management, principles of Web deployment, multimedia principles, content expertise, and more. It requires an interdisciplinary team with time and resources to dedicate to the task.

The benefits derived from the complex and lengthy process of developing a hybrid course can justify the effort. WBTs and self-paced courses can relieve the faculty crush and make better use of campus resources. At Metro, the labs were overflowing, and the full-time faculty numbers were not great enough to meet the demand for introductory courses. No additional resources were in sight. Our department service classes had increased in size and number, and we were reaching a point where our full-time faculty were so occupied with teaching these courses, that they were not free to teach our major courses. A hybrid plan would free more full-time faculty to teach upper level courses and reduce the ratio of full-time to part time faculty.

\section{The MSCD Computer Skills WBT}

In 1997, three CIS faculty were given a Mini-technology grant of $\$ 22,000$ and a semester of half-release time to develop an Introduction to Computers WBT. They produced an Intranet course that students could use to acquire computer literacy skills without taking the classroom version of the course. The MSCD Computer Skills WBT was placed on the school server. The proposal included creating a Testing Center at Metro where students could test out of the 1010 Introduction to Computers course. If they were already computer literate, they could challenge the requirement and be given the opportunity to pass the Computer Literacy screening. If they needed to brush up on some basic skills, learn the specifics of the Metro computer systems, or take the full eight-module WBT (listed in Figure 2 ), they could do so on a self-paced basis. If necessary, they could take a classroom or Internet section of the full Introduction to Computers course. In this way, there was an expedient variation of the computer literacy requirement for every Metro student. 


\section{Hybrid Delivery of Computer Literacy Requirements}

\begin{tabular}{|l|l|}
\hline Module 1 & Understanding Computer Concepts - Hardware \& Software \\
\hline Module 2 & Navigating in Windows - File management - GUI and operating systems \\
\hline Module 3 & Using Word Processing Concepts \\
\hline Module 4 & The MSCD Network \\
\hline Module 5 & Understanding Computer Communications \\
\hline Module 6 & Using UNIX MiniComputer Systems \\
\hline Module 7 & Doing Online Internet Research \\
\hline Module 8 & Using Spreadsheets and Charts \\
\hline
\end{tabular}

Figure 2: The MSCD Basic Computer Skills WBT

Once the computer literacy entrance requirement for the Computer Applications for Business course was thus adjusted, the hybrid model for delivering this Business School course could also be introduced. From instructor surveys of their classes for the last three years, we knew that fifty per cent or more of the students in the CIS 2010 course had their own computers. A third of them had their own Internet Service Providers, in addition to use of the text-based Internet services at Metro. We could therefore conclude that the majority of our students had private access to equipment that was comparable to ours at the "originating site" - a condition that Payson (1998) says is necessary for high quality mediated instruction. We could be comfortable adopting a hybrid model that used the Web for a third of the class instruction. From working on Internet-delivered courses and studying online learning, we knew that the ubiquitous Web also had an acceptable track record for electronic tutelage (Kliewer, 1993; Luna, 1997; Mawhinney, 1998.)

\section{The Hybrid CIS 2010 Model}

In 1999, two CIS faculty has won a PD grant to design a new curse format to handle the increased number of students and sections. The proposed plan for a hybrid delivery of the three-semester-hour 2010 course consisted of a shared teaching arrangement with a Web component. Each section ( 25 sections reduced to 12 with 50 students per section) would meet in large lecture classroom for a theory lecture once a week, given by a full-time faculty master teacher. Internet Web-based distance learning with student activities, cbts, and class projects would comprise a second component of the class. If a student wished to attend a formal instructor-led session for the Web component, there would be open labs with an adjunct professor supervising the lab. Otherwise the student could cover this component independently. Finally, there would be formal required student labs for structured lab activity once a week. These would be taught by adjunct professors. There would also be numerous open student labs scheduled throughout the week, where lab monitors would be available to help students informally, on a one-on-one basis.

This hybrid model would allow students to learn in a modified, any time any place, just-in-time mode. The Internet content component would allow all 2010 students to experience some of the same online features that the students of the existing Internet delivered section of 2010 do - including the Forum, Chat, Weblinks, email, StudentProfiles, performing Web searches, shared work spaces and other distance education benefits. The students in the hybrid delivered course would also receive more personalized and individualized one-on-one interaction with an instructor for two of the three class sessions. By taking advantage of the best characteristics of full-time professors, adjunct professors, and the interactivity of the Web, the Hybrid CIS 2010 model could please students, faculty, and administrators alike.

\section{Conclusions}

The hybrid delivery model for CIS Computer Applications for Business courses promises several things, among them the better use of resources--student resources, faculty re- 


\section{Kathryn A. Marold \& János T. Füstös}

sources, and the Metro physical plant resources. It promises individualized, interactive learning and a quality curriculum. It promises better use of technology for learning. The measurable outcomes that were proposed were:

- The student learning environment would be more flexible.

- The student learning environment would be more personal, as a result of more online communication and small adjunct-led sessions.

- The master teacher lectures would be consistently high quality, focused presentations by highly experienced instructors.

- The ratio of full-time to part-time instructors would be improved.

- The number of students the course could serve could be increased.

- The amount of interactive experiential learning time for students would be increased.

The hybrid plan for delivering the Computer Applications for Business course is not without resistance. There is some skepticism and reluctance on the part of administrators and faculty alike. (The students polled have heartily endorsed the proposal!) There are suggestions that the resources required for conversion to the hybrid plan will not save, but deplete more resources. There are threatened faculty members, uncertain administrators who cling to the tried and true pedagogy of the older models, and nervous IT personnel that anticipate greater, not less, traffic in the campus labs. A pilot year will test the hybrid model.

\section{Summary}

The CIS faculty who are involved in the pilot hybrid delivery model will be busy in the next year, developing content and training adjunct professors and lab technicians. We intend to use Jones e-Education to deploy the Internet portion, manage the site and help develop the course content. Jones e-Education Services delivers all of our Internet extended education courses on a redundant server. This is an undertaking of considerable magnitude. Changing more than twenty sections of a required Business School course impacts many students and faculty. However, it is an undertaking worthy of our effort. We members of IS community and particularly those allied with CIS departments, must lead the way. Our role as agents of change within academic institutions dictates that we constantly work on improving systems, despite the risk. Despite the fact that many of our more traditional colleagues look askance, and declare that we "are at it again", the hybrid delivery model will be implemented on a pilot basis in the fall of 2001. The effectiveness of the new hybrid model won't be known until we are well into the until we are well into the next millennium. It is an appropriate time to embrace a new teaching model.

\section{References}

Bowman, B., Grupe, F., \& Simkin, M. (1995). Teaching end-user applications with computer-based training: theory and an empirical investigation. Journal of End User Computing, 7, (2) 12-17.

Burgstahler, S. (1997). Teaching on the Net: what's the difference? T.H.E. Journal, 24, (9) 61-64.

Dager, N. (1998). Little Web Schoolhouse. AV Video Multimedia Producer, 20, (12) 15.

Hall, B., \& Sprenger, PP. (1997). Team Training. Internet World. 58-60.

Kliewer, H. (1993). Enabling learning through multimedia. OS/2 Professional, 70-74.

Kroder, S., Suess, J., \& Sachs, D. (1998). Lessons in launching webbased graduate courses. T.H.E. Journal, 25, (10) 66-69.

Luna, C. J., \& McKenzie, J. (1997). Testing multimedia in the Community college classroom. T.H.E. Journal, 47, (7) 78-81.

Ganger, R. (1990). Computer based training works. Personnel Journal, $69,(9) 84$

Marold, K. A. (1998) (a). Meauring the success of implementing multimedia CBTs in business. In Mahmood, M..A. \& Szewczak, E. (Ed), Measuring Information Technology Investment Payoff: Contemporary Approaches. Idea Group Publishing, Hershey, PA.

Marold, K. A. (1998) (b). From CAI to WBT: the evolution of electronic tutelage. Proceeding of the Twenty-Sixth Annual International Business Schools Computing Association, Denver, CO, July.

Marold, K. A. (1994). Constituent Elements of the Electronic Noetic. Ph.D. dissertation, University of Denver.

Mawhinney, C. et al. (1998). The MSCD experience with putting business courses online. Proceedings of the Twenty-Sixth Annual International Business Schools Computing Association, Denver, CO, July.

McGrath, B. (1998). Partners in Learning: twelve ways technology changes the teacher-student relationship. T.H.E. Journal, 25, (9) 58-61.

Molnar, A. R. (1997). Computers in Education: A Brief History. T.H.E. Journal, 24, (11), 63-68.

Payson, Ronald S. (1998). Affordable access to high quality electronically mediated instruction. T.H.E. Journal, 26, (3) 65-67.

Reinig, B., \& Reinig, J. (1998). Supporting higher education with the World Wide Web. Journal of Computer Information Systems, 7683. 


\section{Hybrid Delivery of Computer Literacy Requirements}

Shank, R. (1995). Learning and multimedia software. Presentation for CASI. US West Advanced Technologies Laboratory, Boulder, CO, April 12.

Shayo, C., Gutherie R., \& Igbaria, M. (1999). Exploring the measurement of end user computing success. Journal of End User Computing, 11, (1) 5-14.

Withrow, F. (1997). Technology in education and the next twenty-five years. T.H.E. Journal, 24, (11). Retrieved March 24, 2000, from the World Wide Web:

http://www.thejournal.com/magazine/vault/A1680.cfm

\section{Biographies}

Kathryn Marold is a faculty member of Metropolitan State College of Denver, where she teaches information systems, micro-based software, VisualBasic programming and multimedia courses. Prof. Marold has authored dozens of papers and 11 books on the subject of computer literacy, productivity applications, Internet.

János Füstös is associate professor at Metropolitan State College of Denver, where he teaches computer applications, information systems, and web related courses. Prof. Füstös has authored papers in several languages on managerial and international aspects of information systems, and published and translated 16 books on the subject of computing, and World Wide Web. 